\title{
Article \\ A Biocompatible Ultrananocrystalline Diamond (UNCD) Coating for a New Generation of Dental Implants
}

\author{
Orlando Auciello ${ }^{1,2}$, Sandra Renou ${ }^{3}\left[\right.$ (]) Karam Kang ${ }^{4}$, Deborah Tasat ${ }^{5,6,7}$ (i) and Daniel Olmedo ${ }^{3,8, *}$ (i) \\ 1 Department of Materials Science and Engineering and Bioengineering, Original Biomedical \\ Implants (OBI-USA), University of Texas at Dallas, Dallas, TX 75080, USA; oha120030@utdallas.edu \\ 2 Original Biomedical Implants-México (OBI-México), Hermosillo 83210, Mexico \\ 3 Cátedra de Anatomía Patológica, Facultad de Odontología, Universidad de Buenos Aires, \\ Buenos Aires C1122AAH, Argentina; sandra.renou@odontologia.uba.ar \\ 4 Hoefer Welker, Dallas, TX 75201, USA; karam0225@gmail.com \\ 5 Cátedra de Histología y Embriología, Facultad de Odontología, Universidad de Buenos Aires, \\ Buenos Aires C1122AAH, Argentina; dtasat@gmail.com \\ 6 Escuela de Ciencia y Tecnología, Universidad Nacional de General San Martín, San Martín 1650, Argentina \\ 7 Instituto de Tecnologías Emergentes y Ciencias Aplicadas (ITECA), CONICET_-Universidad Nacional de \\ General San Martín, San Martín 1650, Argentina \\ 8 Consejo Nacional de Investigaciones Científicas y Técnicas (CONICET), Buenos Aires C1425FQB, Argentina \\ * Correspondence: daniel.olmedo@odontologia.uba.ar
}

Citation: Auciello, O.; Renou, S.; Kang, K.; Tasat, D.; Olmedo, D. A Biocompatible Ultrananocrystalline Diamond (UNCD) Coating for a New Generation of Dental Implants. Nanomaterials 2022, 12, 782. https:// doi.org/10.3390/nano12050782

Academic Editors: Ali Ramazani and Roya Zandparsa

Received: 31 December 2021 Accepted: 17 February 2022 Published: 25 February 2022

Publisher's Note: MDPI stays neutral with regard to jurisdictional claims in published maps and institutional affiliations.

Copyright: (c) 2022 by the authors Licensee MDPI, Basel, Switzerland. This article is an open access article distributed under the terms and conditions of the Creative Commons Attribution (CC BY) license (https:// creativecommons.org/licenses/by/ $4.0 /)$.

\begin{abstract}
Implant therapy using osseointegratable titanium (Ti) dental implants has revolutionized clinical dental practice and has shown a high rate of success. However, because a metallic implant is in contact with body tissues and fluids in vivo, ions/particles can be released into the biological milieu as a result of corrosion or biotribocorrosion. Ultrananocrystalline diamond (UNCD) coatings possess a synergistic combination of mechanical, tribological, and chemical properties, which makes UNCD highly biocompatible. In addition, because the UNCD coating is made of carbon (C), a component of human DNA, cells, and molecules, it is potentially a highly biocompatible coating for medical implant devices. The aim of the present research was to evaluate tissue response to UNCD-coated titanium micro-implants using a murine model designed to evaluate biocompatibility. Non-coated $(n=10)$ and UNCD-coated $(n=10)$ orthodontic Ti micro-implants were placed in the hematopoietic bone marrow of the tibia of male Wistar rats. The animals were euthanized 30 days post implantation. The tibiae were resected, and ground histologic sections were obtained and stained with toluidine blue. Histologically, both groups showed lamellar bone tissue in contact with the implants (osseointegration). No inflammatory or multinucleated giant cells were observed. Histomorphometric evaluation showed no statistically significant differences in the percentage of BIC between groups (C: $53.40 \pm 13 \%$ vs. UNCD: $58.82 \pm 9 \%, p>0.05$ ). UNCD showed good biocompatibility properties. Although the percentage of BIC (osseointegration) was similar in UNCDcoated and control Ti micro-implants, the documented tribological properties of UNCD make it a superior implant coating material. Given the current surge in the use of nano-coatings, nanofilms, and nanostructured surfaces to enhance the biocompatibility of biomedical implants, the results of the present study contribute valuable data for the manufacture of UNCD coatings as a new generation of superior dental implants.
\end{abstract}

Keywords: ultrananocrystalline diamond (UNCD) coating; surface treatment; biotribocorrosion; biocompatibility; titanium micro-implants; osseointegration

\section{Introduction}

Pure titanium (Ti) and its alloys are widely used to manufacture dental and orthopedic implants, among other medical applications, given their appropriate mechanical properties and biocompatibility [1,2]. Osseointegratable Ti dental implants have revolutionized clinical 
dental practice and have shown a high rate of success [3,4]. However, some technical and/or biological complications associated with Ti dental implants can occur $[5,6]$.

No metal or metal alloy is completely inert in vivo [7]. One of the possible causes of failure of a Ti implant after initial success is biotribocorrosion, which is the combined effect of mechanical, biochemical, and electrochemical factors in a biological environment [8-10]. Biotribocorrosion causes the release of ions/metallic particles from the Ti surface into the surrounding tissue, thus allowing for their possible systemic dissemination and deposition in distant organs [11].

Several studies have reported the presence of $\mathrm{Ti}$ particles in human peri-implant tissues $[6,9,12]$. In line with studies reported in the literature, our research group histologically demonstrated the presence of Ti particles in peri-implant tissue surrounding failed human dental implants [13], in oral mucosa in contact with the implant cover screw [14], in cells exfoliated from the oral mucosa in contact with a titanium dental implant [15], and in lesions found close to a Ti dental implant $[16,17]$.

In situ degradation of a metallic implant alters its structural integrity, and the released ions / particles can have different biological effects [7,18-22]. Aside from creating new metalfree implant materials that can be used for oral rehabilitation purposes, it is paramount to design enhanced implant surface treatments to minimize the risk of implant biotribocorrosion and the health problems associated with these processes. A number of coatings and micro- and nanostructured surfaces have been developed in an attempt to improve implant biocompatibility and osseointegration and prevent the release of ions/particles from the implant surface into the biological milieu. The properties of these coatings are evaluated using different biological parameters [23,24].

An ideal surface treatment would render the coating highly resistant to chemical attack and would allow achieving micro- and nano-roughness, which has been shown to enhance osseointegration $[25,26]$. Nanoscale-tailored surfaces can have a more profound and significant impact on the fates of cells compared with microscaled surfaces [27-29]. A number of studies have engineered nanotopological features including nanogrooves, nanofibers, nanodots, nanotubes, and complex shaped patterns [30] and have investigated the significant effects of nanostructured implant surfaces on osteogenic differentiation and the immune system [31].

Carbon-based materials [32,33] have emerged as promising candidates for implant coatings in view of their good tissue compatibility, resistance to chemical attack by body fluids, radiation resistance (which makes them suitable for sterilization processes), hemocompatibility, optimal mechanical and tribological properties (ultrahigh hardness, low friction coefficient, negligible wear), and good adhesion to $\mathrm{Ti}$ [34].

The ultrananocrystalline diamond (UNCD) coating described in this article is one of the carbon coatings available today and was developed [35-40] and patented [38,41] by Auciello et al. This novel UNCD coating exhibits a unique synergistic combination of outstanding mechanical (highest hardness compared to all other carbon-based coatings [37]) and tribological (lowest coefficient of friction compared to all other carbon-based coatings [36,37]) properties, unique resistance to chemical corrosion by any fluid [37] (including body fluids [40]), high electrical conductivity when inserting $\mathrm{N}$ atoms in the grain boundaries providing electrons for conduction or $\mathrm{B}$ atoms replacing $\mathrm{C}$ atoms in the diamond grain lattice and providing electrons to the electric conduction band [37,42], and exceptional biocompatibility properties [23,37,40,43]. More specifically, its hardness (98 GPa) [37] is similar to that of a diamond gem (100 GPa) and thus greater than that of any other material in thin film form. The UNCD coating exhibits an extremely high fracture resistance/coefficient and practically no wear and has one of the lowest coefficients of friction $(\sim 0.02-0.04)$ compared to coatings available today for industrial products (mechanical pump seals and bearings [37]) and implantable prostheses (hips, knees, and so forth) for clinical use. UNCD is extremely resistant to chemical corrosion by any fluid, including strong acids like HF and body fluids. 
As compared to other types of diamond-based coatings, the surface structure of UNCD films facilitates adhesion, proliferation, and metabolism of different cell types, and thus resembles the nanoscale extracellular matrix of tissue [44]. As shown by studies evaluating the interaction between UNCD films and osteoblasts, fibroblasts, cortical neurons, and cortical stem cells, UNCD films are a suitable, non-toxic support surface for cell growth and proliferation [45-49].

Nanocrystalline diamond (NCD) and UNCD coatings have also been shown to be useful for biosensing post-surface functionalization [50-52]. Auciello et al. showed the UNCD coating to be an extremely biocompatible/eye-fluid-corrosion-resistant coating to encapsulate a Si microchip (artificial retina), implantable inside the human eye to restore partial vision to people blinded by retinitis pigmentosa (genetically induced degeneration of retina photoreceptors) [23]. Other researchers have evaluated the use of other diamond structures [53,54] and UNCD coatings [55] for ophthalmological devices, focusing on restoring sight to patients with retinitis pigmentosa. UNCD has been proposed as a coating for biomedical devices, such as coxofemoral prostheses, dental implants, cardiac valves, and ocular devices [23,36].

UNCD can be micromachined to produce tailored micro-nano-electro-mechanical systems (MEMS/NEMS) [35], such as biosensors and drug delivery devices; all these systems are based on UNCD films [37]. UNCD films are grown using Microwave Plasma Chemical Vapor Deposition (MPCVD) or Hot Filament Chemical Vapor Deposition (HFCVD). The HFCVD method currently yields more homogenous films on large areas (up to $300 \mathrm{~mm}$ in diameter) and is being used for manufacturing commercial industrial products such as UNCDcoated mechanical pump seals and bearings developed by Advanced Diamond Technology, a company founded by Auciello and colleagues in 2003 (www.thindiamond.com, accessed on 31 December 2021). UNCD thin films grown on metallic, semiconductor, and insulating

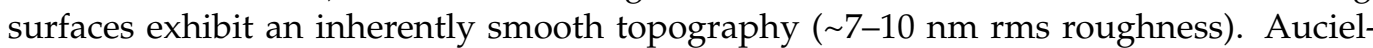
los' group demonstrated that a nanometer-scale-thick tungsten (W) layer ( 50-100 nm) grown on the surface of any substrate used to grow UNCD films induces much denser and smoother ( 3-5 $\mathrm{nm}$ rms surface roughness) UNCD films than films grown without the W layer [39].

In view of the mechanical and chemical properties of UNCD coatings, the aim of this study was to evaluate tissue response to UNCD-coated Ti micro-implants using a murine model to assess the biocompatibility of the UNCD coating.

\section{Materials and Methods}

\subsection{Implants}

Orthodontic Ti micro-implants $5 \mathrm{~mm}$ in length and $1.3 \mathrm{~mm}$ in width were used (Ti-6Al$4 \mathrm{~V}$, AbsoAnchor ${ }^{\circledR} \mathrm{NH}$ 1312-05, Dentos Inc, Daegu, Korea) (Figure 1). The micro-implants were assigned to one of two groups: a Control group $(C)$, which included non-coated micro-implants $(n=10)$, and an Experimental group (E) consisting of UNCD-coated microimplants $(n=10)$.

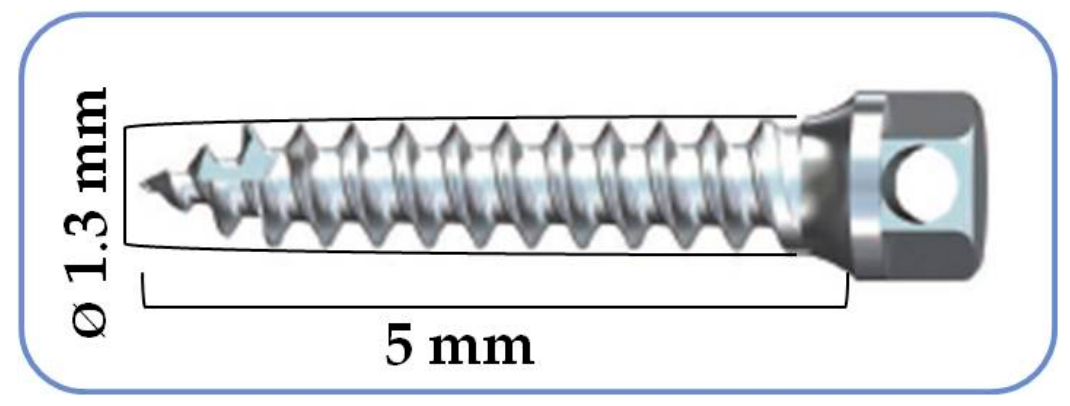

Figure 1. Schematic drawing of a micro-implant (AbsoAnchor ${ }^{\circledR}$ NH 1312-05, Dentos Inc., Daegu, Korea) showing implant size. 


\subsection{Method to Grow a Tungsten (W) Interface Layer on Ti Micro-Implants}

A tungsten $(\mathrm{W})$ interface layer was grown on the Ti micro-implant surface using conventional RF magnetron sputtering. Magnetron sputter-deposition was carried out using an input RF power of $150 \mathrm{~W}$ and an Ar gas flow of $30 \mathrm{sccm}$ (mTorr-range pressure) at room temperature to strike a plasma discharge on the surface of a solid $\mathrm{W}$ target in the magnetron system. The Ar ions impacting on the surface of the $\mathrm{W}$ target induce ejection of $\mathrm{W}$ atoms that travel across the space between the target and the Ti substrate to land on the Ti surface and induce the growth of the $\mathrm{W}$ layer.

\subsection{Method to Grow a UNCD Coating on W-Coated Ti Micro-Implants}

The UNCD film was grown on the surface of W-coated Ti micro-implants employing the Microwave Plasma Chemical Vapor Deposition (MPCVD) technique using a commercial IPLAS (Innovative Plasma Systems GmbH, Troisdorf, Germany) MPCVD system. The novel patented UNCD growth process involves introducing an Ar-rich (99\%)/CH4 (1\%) gas mixture into the MPCVD chamber, evacuated of air to produce a base pressure of $\sim 5 \times 10^{-7}$ Torr. A mixture of $\mathrm{Ar}(49.2 \mathrm{sccm}) / \mathrm{CH} 4(0.8 \mathrm{sccm})$ gas was flown into the evacuated chamber producing a pressure of 90 mbar. Microwave power (1200 watts) was coupled onto the gas, producing a plasma that generates C2-dimers (main UNCD nucleation species), $\mathrm{CH}_{3}, \mathrm{CH}_{2}$, and $\mathrm{CH}$ radicals, which induce the growth of the UNCD films upon impacting on the substrate surface [37]. UNCD films were grown on heated $\left(800^{\circ} \mathrm{C}\right)$ Ti implant samples coated with a $\sim 100 \mathrm{~nm}$ W layer with the surface seeded with nanocrystalline diamond particles embedded on the W surface by ultrasound waves in an ultra-sonicator with a solution of nano-diamond particles in methanol. After the initial seeding, extensive surface cleaning involving sequential exposure of the surface to solvents was performed to remove all large particulates from the substrate surface prior to film growth. UNCD films were subsequently grown for different periods of time to achieve the desired film thickness $(\sim 0.5-1 \mu \mathrm{m})$.

\subsection{Physical-Chemical Characterization of the Implant Surface}

Samples of micro-implants from both groups were examined using scanning electron microscopy (SEM Zeiss Supra model 40, Oberkochen, Germany). For SEM imaging, the samples were coated with a thin $(20 \mathrm{~nm})$ layer of silver in a vacuum evaporator to make them electrically conductive and enable optimum SEM imaging. In addition, the chemical composition of the samples was determined using Energy-dispersive X-ray Spectroscopy (EDS, INCAx-sight model, Oxford Instruments, High Wycombe, UK), with an analytical least detectable dose of $0.5 \%$.

\subsection{Experimental Animals}

Male Wistar rats, $120 \mathrm{~g}$ body weight, were used. The animals were housed under standard conditions, receiving water and food ad libitum and under 12:12 light-dark cycles and controlled temperature $\left(22-24{ }^{\circ} \mathrm{C}\right)$ conditions. The protocol was approved by the Institutional Experimentation Committee (School of Dentistry of the University of Buenos Aires, Resolution Number 006/2015). Adequate measures were taken to minimize animal pain and discomfort. All procedures were performed in compliance with the National Institutes of Health (NIH) guidelines for the care and use of laboratory animals (NIH Publication-Guide for the Care and Use of Laboratory Animals: Eighth Edition, 2011) and the guidelines of the School of Dentistry of the University of Buenos Aires (Res. (CD) 352/02 and Res. (CD) 694/02).

\subsection{Surgical Procedure}

The animals were anesthetized by intraperitoneal injection of a solution of $8 \mathrm{mg}$ of ketamine chlorhydrate (Fort Dodge ${ }^{\circledR}$, La Plata, Provincia de Buenos Aires, Argentine) and $1.28 \mathrm{mg}$ of xylazine (Bayer, Leverkusen, Germany) per $100 \mathrm{mg}$ of body weight. Implantation inside the medullary cavity of the tibiae was performed following the technique described 
by Cabrini et al. [56]. A non-coated micro-implant was placed inside the medullary compartment of the left tibia (C Group) and a UNCD-coated micro-implant was placed inside the medullary compartment of the right tibia (UNCD Group). Both lower limbs were shaved using an electric shaver (Philips ${ }^{\circledR}$, Buenos Aires, Argentina), and a $1.5 \mathrm{~cm}$ incision was made along the tibial crest using a surgical blade $\left(\mathrm{N}^{\circ} 11\right.$ Bard Parker $\left.{ }^{\circledR}\right)$. The muscles and periosteum were dissected to expose the metaphyseal and diaphyseal region of the outer side of the tibia. A $1.5 \mathrm{~mm}$ hole was drilled through the bone by rotating a round burr (Dentsply Maillefer, Tulsa, OK, USA) manually to avoid heating and ensuing necrosis of the bone tissue. Each implant was placed inside the hematopoietic bone marrow, parallel to the longest axis of the tibia. The tissues were repositioned, and the skin was sutured with separate stitches (Vicryl ${ }^{\circledR} \mathrm{N}^{\circ} 3.0$, Johnson \& Johnson, New Brunswick, NJ, USA). No antibiotic therapy was administered. Thirty days post implantation, all the animals were euthanized by anesthetic overdose, and the tibiae were resected, fixed in $10 \%$ buffered formalin, and radiographed.

\subsection{Histological Processing}

The tibiae were processed and embedded in acrylic resin. Longitudinal histological sections were obtained using the micro-grinding system EXAKT 300 CP \& 310 CP Precision Parallel Control (EXAKT, Hamburg, Germany) and stained with toluidine blue $1 \%$ for histological examination by light microscopy.

\subsection{Histomorphometry}

The histological sections were analyzed histomorphometrically using an optical photomicroscope (Leica, DM 2500, Wetzlar, Germany) with LAS EZ software (Leica Application Suite, Wetzlar, Germany) at a magnification of $400 \times$. The area of peri-implant bone tissue and percentage of osseointegration (bone-implant contact: BIC) were determined.

\subsection{Statistical Analysis}

The data were statistically analyzed using Student's $t$-test. Values are expressed as mean and SD; statistical significance was set at $p<0.05$.

\section{Results}

\subsection{Growth of W Interface Layer}

The $\mathrm{W}$ layers grown by magnetron sputter-deposition were about 50 to $10 \mathrm{~nm}$ thick and had a surface roughness of about $6 \mathrm{~nm}$ rms, as measured using Atomic Force Microscopy (AFM). Scanning Electron Microscopy (SEM) and AFM studies showed that UNCD films grown on a substrate surface without the $W$ layer exhibited a surface roughness of about $20 \mathrm{~nm}$ rms, while UNCD films grown on a $100 \mathrm{~nm}$ thick W layer showed a surface roughness of about $6.3 \mathrm{~nm}$ rms.

\subsection{Growth of the UNCD Coating}

UNCD coatings grown on the characteristic screw-type dental implants using the MPCVD process exhibited an extremely dense/pin-hole-free structure conformal to the screw-type implant, as shown by SEM (Figure $2 \mathrm{a}$ ). Figure $2 \mathrm{~b}$ shows the surface roughness of the UNCD coating as measured by the well-known Atomic Force Microscopy (AFM) technique. The AFM technique involves scanning a sharp metal tip, integrated in a cantilever, over the surface of the sample. A laser beam reflecting from the top surface of the cantilever is directed to a sensor, producing the image of a surface with atomic scale resolution. HRTEM studies showed that the UNCD films grown on Ti exhibited the typical grain size of 3-5 nm (Figure 2c). 


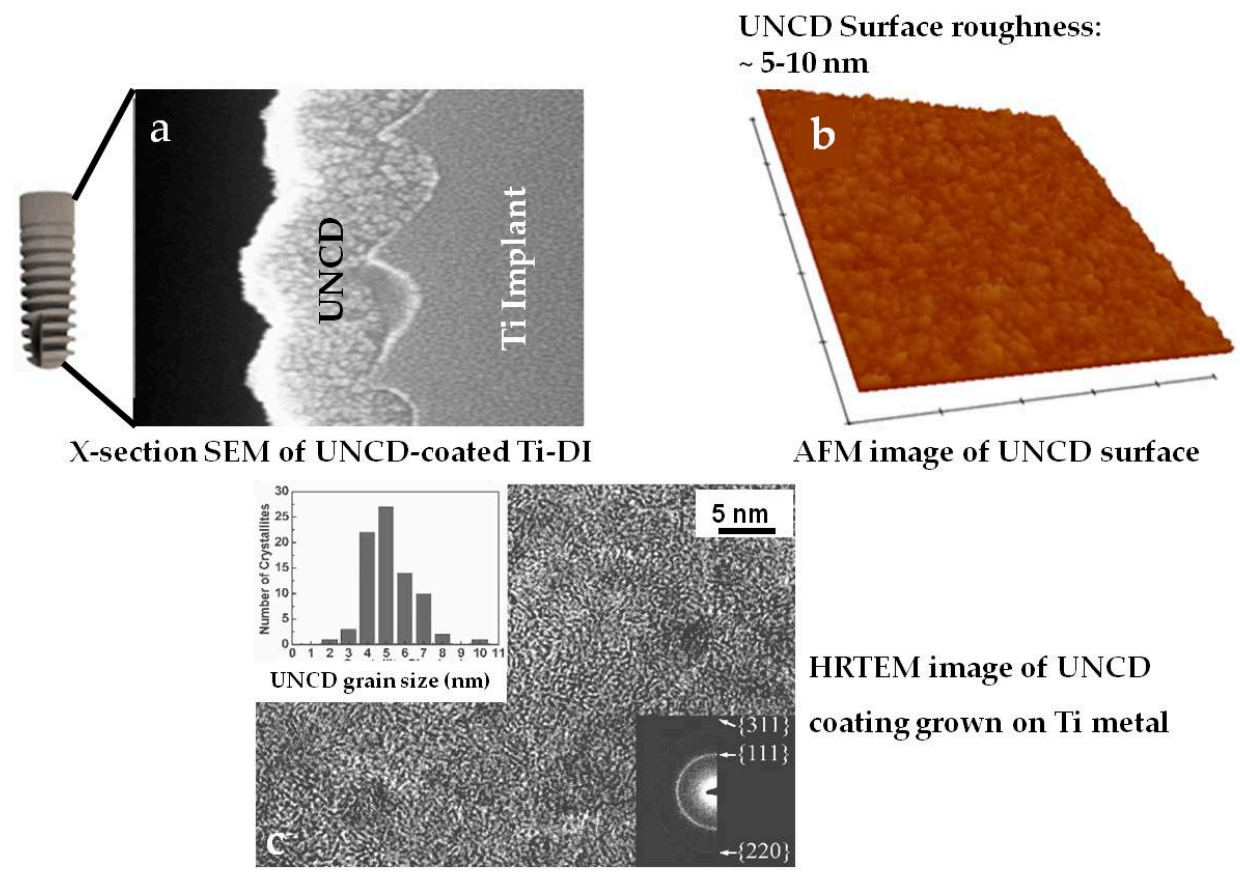

Figure 2. (a) Cross-section SEM image of a UNCD coating grown on a Ti micro-implant (note the extremely dense/conformal structure of the UNCD coating with a nanoscale surface roughness on the Ti implant); (b) surface roughness of the UNCD coating measured by Atomic Force Microscopy (AFM); (c) High-Resolution Transmission Electron Microscopy (HRTEM) image of the UNCD grown on a Ti micro-implant sample showing the typical UNCD grain size of 3-5 nm (the insert shows the electron diffraction pattern obtained in the HRTEM study, showing the (111), (311), and (220) rings characteristic of the diamond structure with nanograins).

\subsection{SEM Imaging and EDS Analyses of Uncoated and UNCD-Coated Ti Micro-Implants}

As shown by SEM, the surface of the uncoated Ti micro-implants in Group C showed all the typical features of a machine-finished surface (Figure $3 a, b)$. The surface of the micro-implants in the UNCD group, however, was grainy, with grain sizes ranging from 3-5 nm (Figure 4a,b), and the coating fully covering the Ti surface of the implant.

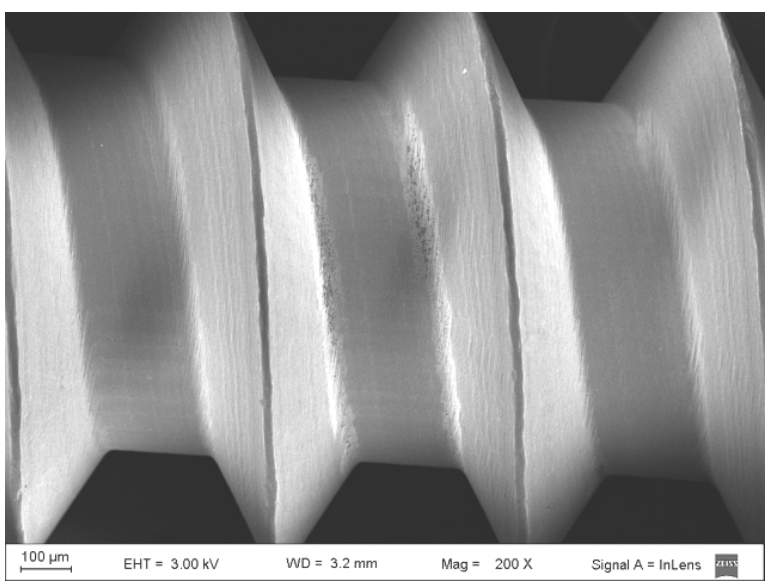

(a)

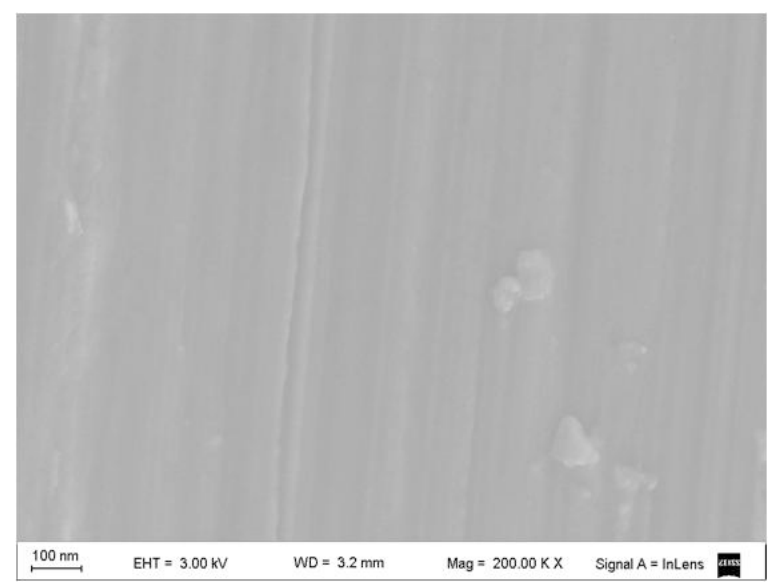

(b)

Figure 3. SEM images showing the surface features of a non-coated Ti micro-implant: (a) lowmagnification $(\times 200)$ SEM image showing the thread structure of the screw-type micro-implant; (b) high-magnification $(\times 200,000)$ SEM image of the machined surface. 


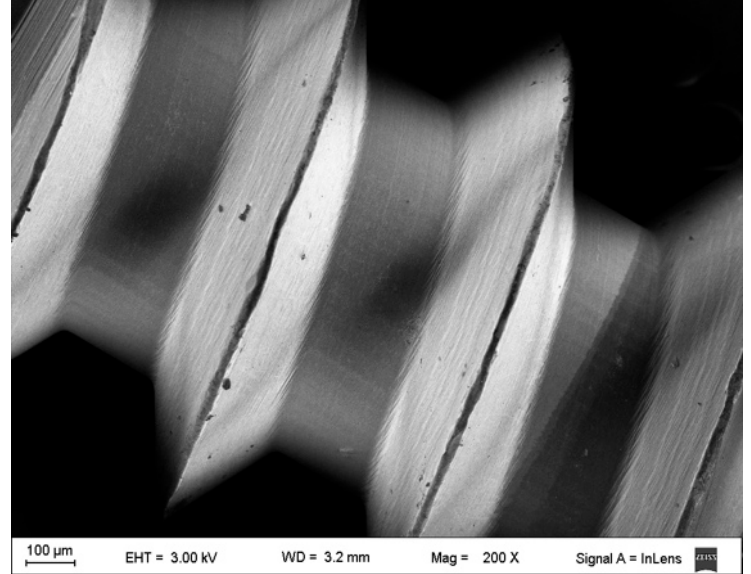

(a)

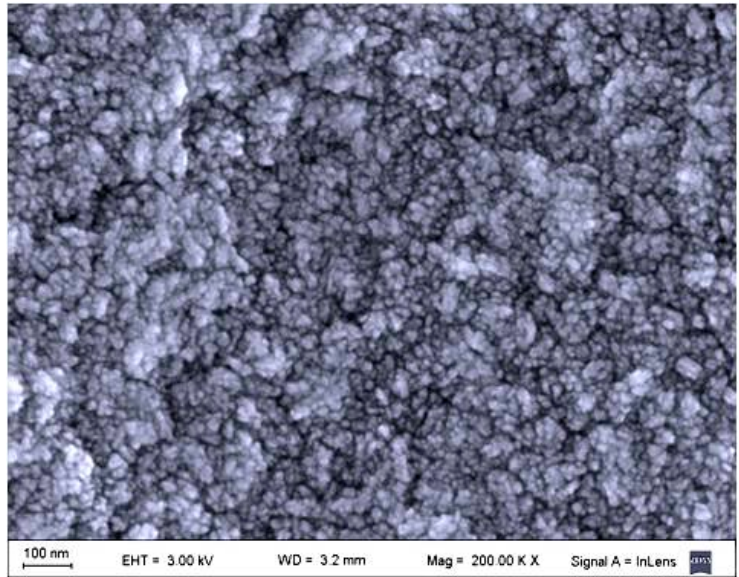

(b)

Figure 4. SEM images showing the surface features of a UNCD-coated Ti implant: (a) low-magnification ( $\times 200)$ SEM image showing the thread structure of the screw-type Ti micro-implant; (b) highmagnification $(\times 200,000)$ SEM image of the UNCD-coated machine-finished Ti surface, showing the nanoscale grainy surface of the UNCD coating.

The elemental composition of the micro-implants was qualitatively confirmed by EDS analysis. Composition of control micro-implants was 6.55\% aluminum (Al), 90.43\% titanium (Ti), and $3.03 \%$ vanadium $(\mathrm{V})$, whereas UNCD-coated micro-implant composition was $42.77 \%$ carbon $(\mathrm{C}), 1.96 \%$ aluminum ( $\mathrm{Al}$ ), $54.60 \%$ titanium (Ti), and 0.68 vanadium $(\mathrm{V})$ (Figure 5a,b).

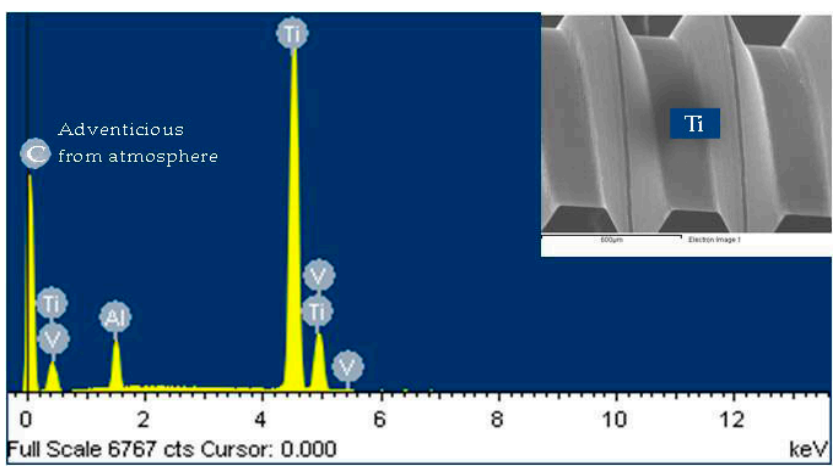

(a)

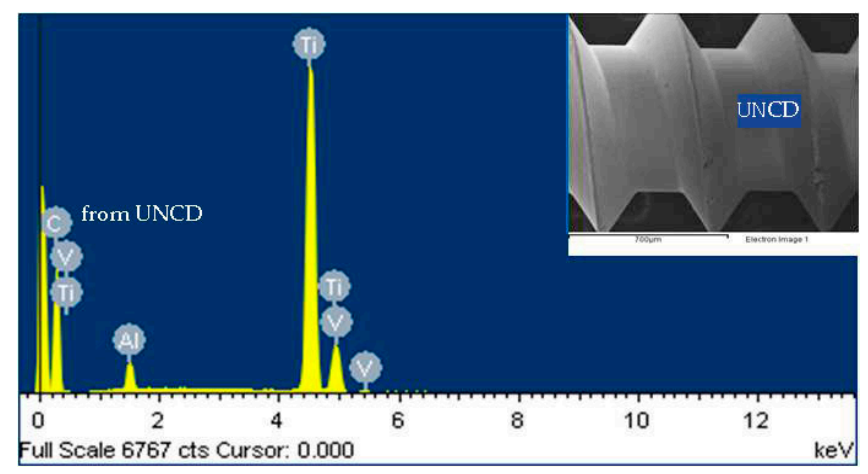

(b)

Figure 5. EDS analysis of micro-implants: (a) spectrum showing peaks corresponding to $\mathrm{Al}, \mathrm{Ti}$, and $\mathrm{V}$ in control micro-implants (the $\mathrm{C}$ peak arises from $\mathrm{C}$ contaminants adsorbed on the surface exposed to the atmospheric environment, as occurs with any material before insertion in the SEM vacuum system); (b) spectrum showing peaks corresponding to C, Al, Ti, and V in UNCD-coated implants.

\subsection{Radiographic Study}

Radiographic evaluation revealed that all implants remained in the implantation site in the diaphyseal area (Figure 6).

\subsection{Histologic Evaluation}

Histologic examination of control and experimental samples revealed areas of lamellar bone in close contact with the surface of the implant (BIC, osseointegration) and areas of bone marrow in contact with the implant surface (myelointegration) thirty days post implantation (Figure $7 \mathrm{a}-\mathrm{c}$ or Figure $8 \mathrm{a}-\mathrm{c}$ ). No inflammatory or multinucleated giant cells were detected. 


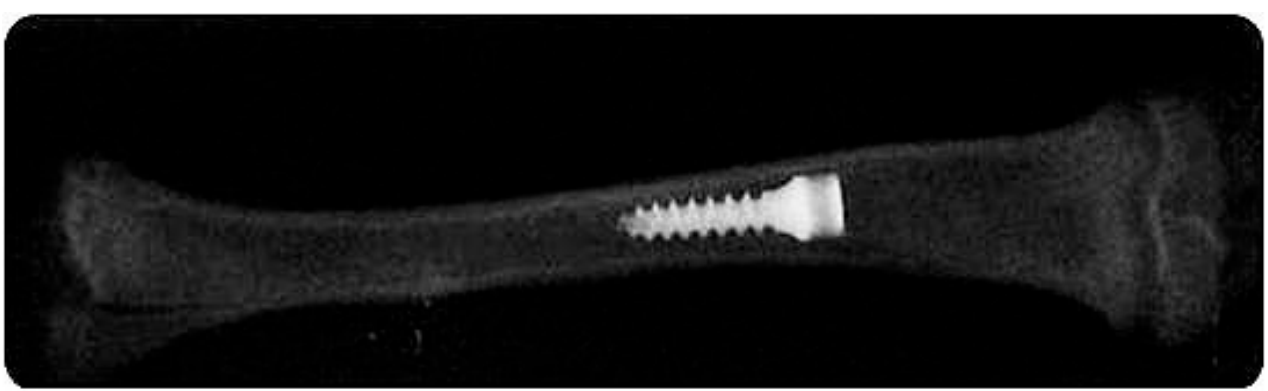

Figure 6. Radiograph showing a microimplant in place in the diaphysis of the rat tibial marrow cavity.

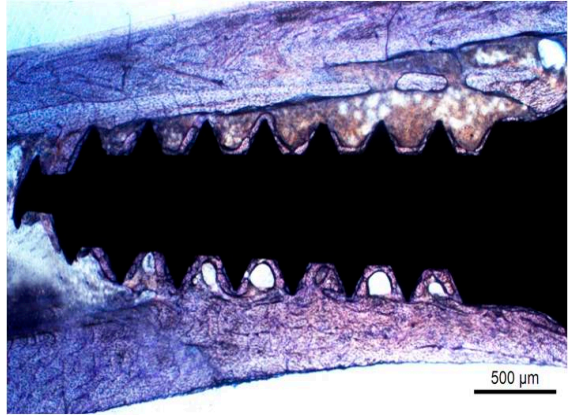

(a)

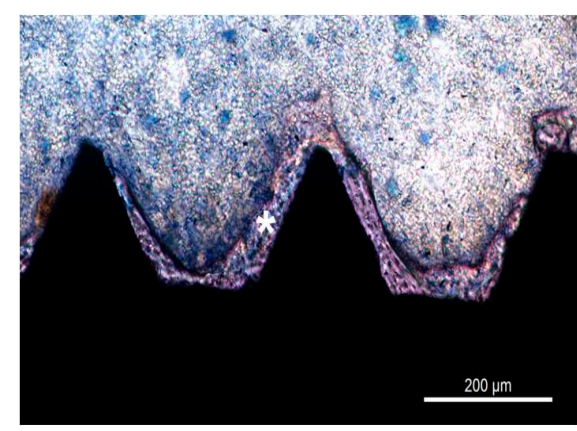

(b)

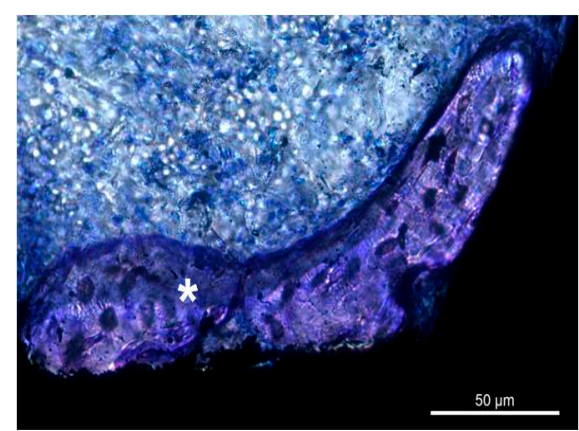

(c)

Figure 7. Histological photomicrographs of control samples showing the interface thirty days post implantation. Note the close contact between the surface of the biomaterial and lamellar bone $(*)$ (osseointegration) and the absence of an inflammatory response. Acrylic resin. Ground sections. Staining with toluidine blue $1 \%$. Original magnification: (a) $25 \times$, (b) $100 \times$, and (c) $400 \times$.

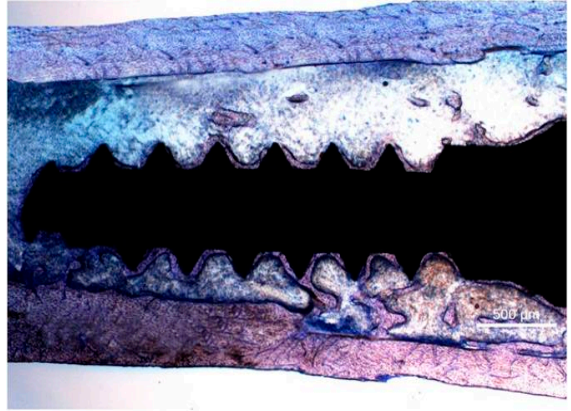

(a)

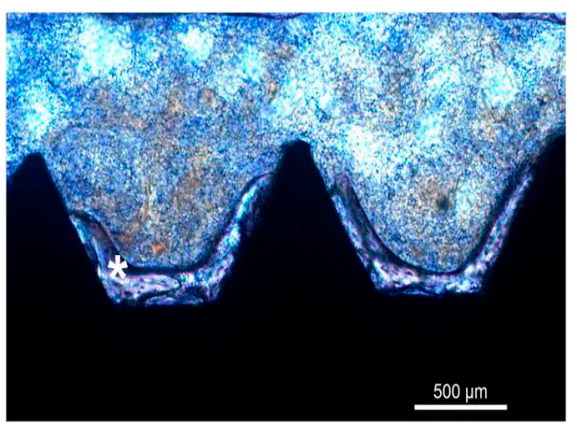

(b)

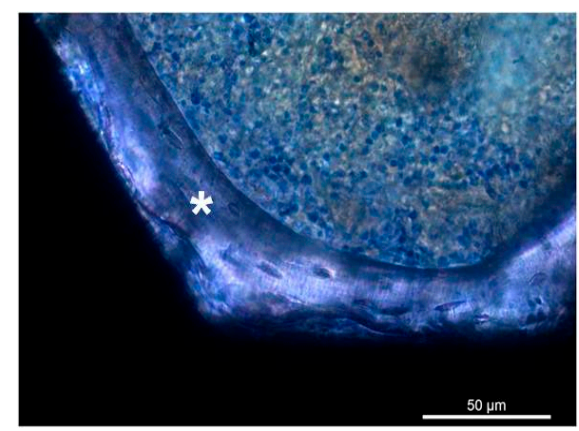

(c)

Figure 8. UNCD histological sections obtained thirty days post implantation. Note the lamellar bone $\left.{ }^{*}\right)$ tissue in close contact with the UNCD surface and the absence of inflammatory infiltrate and multinucleated giant cells. Acrylic resin. Ground sections. Staining with toluidine blue $1 \%$. Original magnification (a) $25 \times$, (b) $100 \times$, and (c) $400 \times$.

\subsection{Histomorphometry}

The histomorphometric study showed no statistically significant differences in the percentage of BIC (osseointegration) between groups (C: $53.40 \pm 13 \%$ vs. UNCD: $58.82 \pm 9 \%$, $p \geq 0.05)$. The area of peri-implant bone tissue was significantly greater in the $\mathrm{C}$ group than in the UNCD group (C: $352932.7 \pm 85.794 \mu \mathrm{m}^{2}$ vs. UNCD: $228244.1 \pm 26.800 \mu \mathrm{m}^{2}, p<0.05$ ) (Figure 9a,b). 


\section{Area of peri-implant bone tissue}

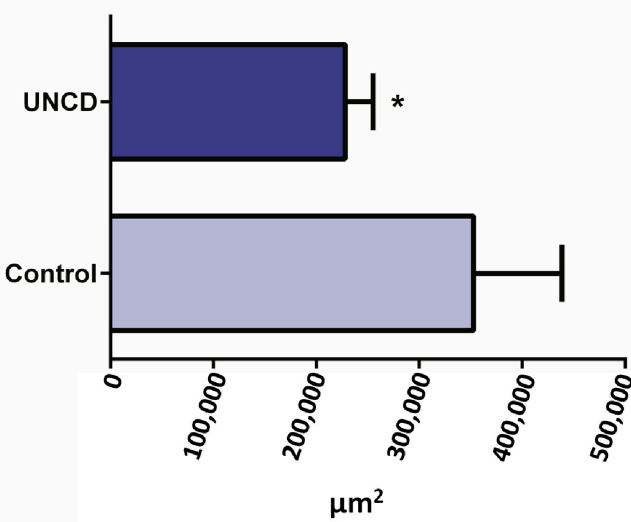

(a)
Bone implant contact (BIC)

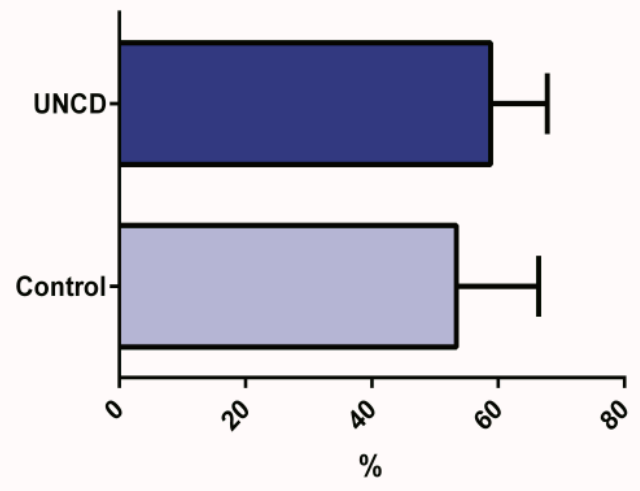

(b)

Figure 9. Histomorphometric study 30 days post implantation. (a) The area of peri-implant bone tissue was significantly greater in the $C$ than in the UNCD group, $\left(^{*}\right) p<0.05$; (b) the percentage of BIC (osseointegration) was similar in both groups, $p \geq 0.05$. The histograms show the mean $\pm \mathrm{SD}$, $p<0.05$.

\section{Discussion}

The potential toxicity and biological risks associated with ions/particles released as a result of biotribocorrosion of metallic implants is a public health concern that particularly affects patients carrying a metallic medical implant, whether orthopedic or dental, since these prostheses must remain inside the body over long periods of time, even decades $[6,14,57,58]$. Managing and controlling biotribocorrosion of a biomedical implant is therefore paramount from a biological, sanitary, metallurgic, economic, and social point of view. Furthermore, studies in the orthopedic and dental literature show that biotribocorrosion of titanium implants can lead to loss of osseointegration [7,57].

It remains unknown whether the presence of inflammation, which causes a decrease in $\mathrm{pH}$, triggers corrosion processes $[59,60]$, or whether corrosion processes, which result in the release of particles, trigger an inflammatory response. Whichever the case, the presence of macrophages loaded with Ti particles is a bioindicator of the occurrence of biotribocorrosion. Once the metallic particles are phagocytized by macrophages, a number of chemical proinflammatory mediators (cytokines, chemokines) are released and can, in turn, trigger a range of biological effects, including osteoclast activation, and thus favor bone resorption, inhibit osteoblasts from secreting bone matrix, and ultimately result in osteolysis [61-63].

There are also reports showing an immune response to Ti triggered by exposure to ions/particles released from an implant $[18,19,64]$. In a previous study, we evaluated biopsies of oral mucosa adjacent to implant cover screws. Positive immunohistochemical staining with antibodies anti-CD68 and anti-CD45RO confirmed the presence of macrophages and $\mathrm{T}$ lymphocytes associated with the metal particles [14]. This finding suggests an immune response mediated by cells and is in line with reports in the literature $[65,66]$.

Histological examination performed in the present study revealed the presence of lamellar bone tissue in contact with the implants (osseointegration). Our histological results showed that UNCD-coated implants were well tolerated by the surrounding tissue and, like the non-coated implants, caused no inflammatory reaction.

The development of peri-implantitis triggered by the presence of metallic particles themselves and/or by their interaction or synergistic effect with periodontal pathogens [67-69] is another documented biological effect of Ti implants that is raising growing concern [67-69].

As to the carcinogenic potential of implants, there are scant reports on the possible development of malignant tumors associated with prosthetic structures in humans [20-22,70]. Nevertheless, there is no clear evidence that biotribocorrosion of Ti implants is not involved 
in carcinogenesis [71]. Of note, $\mathrm{TiO}_{2}$ was classified by the International Agency for Cancer Research as possibly carcinogenic to humans (Group 2B) [72].

Several mechanisms have been proposed to explain the possible association between malignant transformation and a metallic implant device. Features such as valence, particle concentration and size, and hypersensitivity have been proposed as potential factors [70]. Nevertheless, no direct cause-and-effect has been demonstrated in humans to date $[70,71,73,74]$.

Specifically regarding titanium dental implants, 46 cases of squamous cell carcinoma [71,73], one osteosarcoma [20], and one plasmacytoma [21] in the vicinity of a Ti implant have been reported in the scientific literature in English. Some authors have suggested an association between the release of particles from a metallic implant and carcinogenic and mutagenic changes in the oral cavity $[73,75]$. In addition to the aforementioned studies, cases of breast, lung, and prostate metastases associated with dental implants have also been reported in the literature [71,73]. In a previous work, we reported [17] a case of intraosseous metastasis of kidney adenocarcinoma, which to our knowledge is the first report of this type of lesion close to a dental implant. It is important to point out that whereas there are no reports of a benign neoplasm developing in the vicinity of a titanium dental implant, our series included a case of peripheral cemento-ossifying fibroma.

According to Doak el at., evidence for the genotoxicity and carcinogenesis of carbonbased nanomaterials is accumulating, with a clear dependency on physicochemical features, but their long-term impact on human health has yet to be definitively established [76]. There are no reports in the literature suggesting a carcinogenic potential of the UNCD coating. We speculate that because the coating is a carbon-based material and carbon is a component of human tissue, it is highly biocompatible.

It is also known that trace metals can increase the physiological production of reactive oxygen species (ROS), which can lead to tissue damage in the absence of a compensatory increase in antioxidant species [77-79]. Previous experimental studies performed by our research group showed that $\mathrm{TiO}_{2}$ particles were transported in the blood via cells of the mononuclear phagocytic lineage and were deposited in organs with macrophagic activity such as the liver, spleen, and lungs and caused an increase in oxidative stress in lung and liver macrophages $[13,80]$. Toxicity studies performed by our research group allowed establishing a relation between the toxic effects of $\mathrm{TiO}_{2}$ particles and particle size. In line with a number of studies demonstrating that the smaller the particle, the greater its toxicity [81-83], our studies showed that superoxide anion generation was inversely proportional to particle size [84].

With the aims of preventing or limiting the release of $\mathrm{TiO}_{2}$ particles into the biological milieu and avoiding the likely adverse biological effects, UNCD coatings have been developed to optimize implant biocompatibility, improve osseointegration, and reduce the likelihood of biotribocorrosion.

Film adhesion is one of the crucial requirements for any type of coating for biomedical implants. In this regard, it has been demonstrated that UNCD coatings exhibit strong adhesion, even in situations where two UNCD-coated parts rub together due to a strong pushing force, as is the case of UNCD-coated mechanical pump seals [85].

Our group evaluated the in vivo biological effects and biokinetics of UNCD particles compared to the biological response to $\mathrm{TiO}_{2}$ nanoparticles in an experimental animal model [86]. The scant amount of UNCD deposits in the parenchyma of the analyzed organs, the absence of morphological alterations, and the lower oxidative inductions as compared to observations in $\mathrm{TiO}_{2}$-nanoparticle-exposed animals suggest that tissue response would be less aggressive or negligible in the event that the UNCD coating detached from the implant surface. These differences in biological response may be associated with the fact that UNCD coatings are made of carbon (C), a component of human DNA, cells, and molecules, which potentially makes them highly biocompatible coatings for medical implant devices [87].

Interestingly, tissue response to the UNCD coated implant was assessed in vivo in the present study [56]. The experimental model used here was developed by our research group [56]. The basic principle of the model is the osteogenic capacity of the rat tibia bone 
marrow, and it has been used to evaluate the influence of different systemic and local factors on tissue repair. The model provides an isolated microenvironment that is not exposed to microbial contamination or mechanical forces; this controlled environment allows evaluating tissue response to a specific condition, ruling out the interference of confounding variables. Our in vivo model allows implant immobilization. Radiographs confirmed that the biomaterial remained in the same place and position inside the tibial medullary cavity throughout the entire experiment, and thus served as a 3D osteoconductive scaffold.

Nanostructured surfaces have controlled physicochemical properties, including roughness, wettability, surface charge, and topography [26]. The UNCD coating had a surface with nanometric-scale structures and the typical grain size of 3-5 nm, enhancing implant surface interactions with ions, biomolecules, and cells and optimizing biocompatibility. Unlike conventional surface topographies, UNCD provides tailored surface nano-topography where osteoblasts recognize differences in nanometer range, favoring the osseointegration rate of UNCD implants [35,37].

The results of the present study allow concluding that UNCD has excellent biocompatibility properties and, though the percentage of BIC (osseointegration) was similar in UNCD-coated and control Ti micro-implants, its documented tribological properties would make it a superior implant coating material. Although the UNCD coating did not improve the percentage of osseointegration, it could protect against biotribocorrosion of the base material (titanium) and its ensuing deleterious biological effects.

Given the current surge in the use of nano-coatings, nanofilms, and nanostructured surfaces to enhance biocompatibility of biomedical implants, the results of the present study contribute valuable data for the manufacture of UNCD coatings as a new generation of superior dental implants. With regard to the above statement, it is relevant to consider recent $R \& D$ findings of a clinical trial conducted at a world-class clinic in Querétaro, Mexico, in 2018, involving implantation of UNCD-coated commercial Ti-6Al-4V dental implants in thirty-five patients. The results indicate that the biocompatible UNCD coatings will enable a new generation of dental implants that are superior to current metal-based dental implants. A recently published book chapter by our group [88] provides a detailed description of the materials and technological research and development of the UNCD-coated dental implants and of the results obtained in experimental animal studies and clinical trials.

Author Contributions: Conceptualization, O.A., D.T. and D.O.; methodology, O.A., S.R. and D.O.; investigation, O.A., S.R., K.K., D.T. and D.O.; resources, O.A., D.T. and D.O.; writing-original draft preparation, O.A., D.T. and D.O.; writing-review and editing, O.A., S.R., D.T. and D.O.; project administration, O.A., D.T. and D.O.; funding acquisition, O.A., D.T. and D.O. All authors have read and agreed to the published version of the manuscript.

Funding: This research was funded by the University of Buenos Aires, grant number UBACyT 20020190100148BA, and the School of Dentistry of the University of Buenos Aires, grant number FOUBA Res. (CD) N³30/19-01.

Institutional Review Board Statement: The study was conducted according to the National Institutes of Health (NIH) guidelines for the care and use of laboratory animals (NIH Publication-Guide for the Care and Use of Laboratory Animals: Eighth Edition, 2011) and the guidelines of the School of Dentistry of the University of Buenos Aires (Res. (CD) 352/02 and Res. (CD) 694/02). The protocol was approved by the Institutional Experimentation Committee (School of Dentistry of the University of Buenos Aires, Resolution Number 006/2015).

Informed Consent Statement: Not applicable.

Data Availability Statement: The data presented in this study are available on request from the corresponding author.

Acknowledgments: O.A. acknowledges the funding from the University of Texas at Dallas, through his Distinguished Endowed Chair Professor position.

Conflicts of Interest: The authors declare no conflict of interest. 


\section{References}

1. Abdel-Hady Gepreel, M.; Niinomi, M. Biocompatibility of Ti-alloys for long-term implantation. J. Mech. Behav. Biomed. Mater. 2013, 20, 407-415. [CrossRef] [PubMed]

2. Yin, Z.F.; Wu, L.; Yang, H.G.; Su, Y.H. Recent progress in biomedical applications of titanium dioxide. Phys. Chem. Chem. Phys. 2013, 15, 4844-4858. [CrossRef] [PubMed]

3. Buser, D.; Sennerby, L.; De Bruyn, H. Modern implant dentistry based on osseointegration: 50 years of progress, current trends and open questions. Periodontology 2000 2017, 73, 7-21. [CrossRef] [PubMed]

4. Wennerberg, A.; Albrektsson, T.; Chrcanovic, B. Long-term clinical outcome of implants with different surface modifications. Eur. J. Oral Implant. 2018, 11 (Suppl. S1), S123-S136.

5. Halperin-Sternfeld, M.; Sabo, E.; Akrish, S. The Pathogenesis of Implant-Related Reactive Lesions: A Clinical, Histologic and Polarized Light Microscopy Study. J. Periodontol. 2016, 87, 502-510. [CrossRef] [PubMed]

6. Suárez-López Del Amo, F.; Garaicoa-Pazmiño, C.; Fretwurst, T.; Castilho, R.M.; Squarize, C.H. Dental implants-associated release of titanium particles: A systematic review. Clin. Oral Implant. Res. 2018, 29, 1085-1100. [CrossRef] [PubMed]

7. Guglielmotti, M.B.; Olmedo, D.G.; Cabrini, R.L. Research on implants and osseointegration. Periodontology 2000 2019, 79, 178-189. [CrossRef]

8. Tasat, D.R.; Domingo, M.G.; Bruno, M.E.; Guglielmotti, M.B.; Olmedo, D.G. Titanium Nanoparticle Size Influences Trace Concentration Levels in Skin Appendages. Toxicol. Pathol. 2017, 45, 624-632. [CrossRef]

9. Noronha Oliveira, M.; Schunemann, W.V.H.; Mathew, M.T.; Henriques, B.; Magini, R.S.; Teughels, W.; Souza, J.C.M. Can degradation products released from dental implants affect peri-implant tissues? J. Periodontal Res. 2018, 53, 1-11. [CrossRef]

10. Fretwurst, T.; Nelson, K.; Tarnow, D.P.; Wang, H.L.; Giannobile, W.V. Is Metal Particle Release Associated with Peri-implant Bone Destruction? An Emerging Concept. J. Dent. Res. 2018, 97, 259-265. [CrossRef]

11. Kotsakis, G.A.; Olmedo, D.G. Peri-implantitis is not periodontitis: Scientific discoveries shed light on microbiome-biomaterial interactions that may determine disease phenotype. Periodontology 2000 2021, 86, 231-240. [CrossRef]

12. Wilson, T.G., Jr.; Valderrama, P.; Burbano, M.; Blansett, J.; Levine, R.; Kessler, H.; Rodrigues, D.C. Foreign bodies associated with peri-implantitis human biopsies. J. Periodontol. 2015, 86, 9-15. [CrossRef]

13. Olmedo, D.; Fernández, M.M.; Guglielmotti, M.B.; Cabrini, R.L. Macrophages related to dental implant failure. Implant Dent. 2003, 12, 75-80. [CrossRef] [PubMed]

14. Olmedo, D.G.; Paparella, M.L.; Spielberg, M.; Brandizzi, D.; Guglielmotti, M.B.; Cabrini, R.L. Oral mucosa tissue response to titanium cover screws. J. Periodontol. 2012, 83, 973-980. [CrossRef] [PubMed]

15. Olmedo, D.G.; Nalli, G.; Verdú, S.; Paparella, M.L.; Cabrini, R.L. Exfoliative cytology and titanium dental implants: A pilot study. J. Periodontol. 2013, 84, 78-83. [CrossRef] [PubMed]

16. Olmedo, D.G.; Paparella, M.L.; Brandizzi, D.; Cabrini, R.L. Reactive lesions of peri-implant mucosa associated with titanium dental implants: A report of 2 cases. Int. J. Oral Maxillofac. Surg. 2010, 39, 503-507. [CrossRef]

17. Paparella, M.L.; Domingo, M.G.; Puia, S.A.; Jacobi-Gresser, E.; Olmedo, D.G. Titanium dental implant-related pathologies: A retrospective histopathological study. Oral. Dis. 2022, 28, 503-512. [CrossRef] [PubMed]

18. Sicilia, A.; Cuesta, S.; Coma, G.; Arregui, I.; Guisasola, C.; Ruiz, E.; Maestro, A. Titanium allergy in dental implant patients: A clinical study on 1500 consecutive patients. Clin. Oral Implant. Res. 2008, 19, 823-835. [CrossRef] [PubMed]

19. Jacobi-Gresser, E.; Huesker, K.; Schutt, S. Genetic and immunological markers predict titanium implant failure: A retrospective study. Int. J. Oral Maxillofac. Surg. 2013, 42, 537-543. [CrossRef]

20. McGuff, H.S.; Heim-Hall, J.; Holsinger, F.C.; Jones, A.A.; O'Dell, D.S.; Hafemeister, A.C. Maxillary osteosarcoma associated with a dental implant: Report of a case and review of the literature regarding implant-related sarcomas. J. Am. Dent. Assoc. 2008, 139, 1052-1059. [CrossRef]

21. Poggio, C.E. Plasmacytoma of the mandible associated with a dental implant failure: A clinical report. Clin. Oral Implant. Res. 2007, 18, 540-543. [CrossRef] [PubMed]

22. Gallego, L.; Junquera, L.; Baladron, J.; Villarreal, P. Oral squamous cell carcinoma associated with symphyseal dental implants: An unusual case report. J. Am. Dent. Assoc. 2008, 139, 1061-1065. [CrossRef] [PubMed]

23. Xiao, X.; Wang, J.; Liu, C.; Carlisle, J.A.; Mech, B.; Greenberg, R.; Guven, D.; Freda, R.; Humayun, M.S.; Weiland, J.; et al. In vitro and in vivo evaluation of ultrananocrystalline diamond for coating of implantable retinal microchips. J. Biomed. Mater. Res. $B$ Appl. Biomater. 2006, 77, 273-281. [CrossRef] [PubMed]

24. Franchi, M.; Bacchelli, B.; Giavaresi, G.; De Pasquale, V.; Martini, D.; Fini, M.; Giardino, R.; Ruggeri, A. Influence of different implant surfaces on peri-implant osteogenesis: Histomorphometric analysis in sheep. J. Periodontol. 2007, 78, 879-888. [CrossRef]

25. Hacking, S.A.; Boyraz, P.; Powers, B.M.; Sen-Gupta, E.; Kucharski, W.; Brown, C.A.; Cook, E.P. Surface roughness enhances the osseointegration of titanium headposts in non-human primates. J. Neurosci. Methods 2012, 211, 237-244. [CrossRef]

26. Wang, Q.; Huang, Y.; Qian, Z. Nanostructured Surface Modification to Bone Implants for Bone Regeneration. J. Biomed. Nanotechnol. 2018, 14, 628-648. [CrossRef]

27. Huang, Q.; Elkhooly, T.A.; Liu, X.; Zhang, R.; Yang, X.; Shen, Z.; Feng, Q. Effects of hierarchical micro/nano-topographies on the morphology, proliferation and differentiation of osteoblast-like cells. Colloids Surf. B Biointerfaces 2016, 145, 37-45. [CrossRef]

28. Amirian, J.; Lee, S.Y.; Lee, B.T. Designing of Combined Nano and Microfiber Network by Immobilization of Oxidized Cellulose Nanofiber on Polycaprolactone Fibrous Scaffold. J. Biomed. Nanotechnol. 2016, 12, 1864-1875. [CrossRef] 
29. Bruinink, A.; Bitar, M.; Pleskova, M.; Wick, P.; Krug, H.F.; Maniura-Weber, K. Addition of nanoscaled bioinspired surface features: A revolution for bone related implants and scaffolds? J. Biomed. Mater. Res. A 2014, 102, 275-294. [CrossRef]

30. Lim, J.Y.; Donahue, H.J. Cell sensing and response to micro- and nanostructured surfaces produced by chemical and topographic patterning. Tissue Eng. 2007, 13, 1879-1891. [CrossRef]

31. Bajaj, S.; Banerjee, M. Engineering Virus Capsids Into Biomedical Delivery Vehicles: Structural Engineering Problems in Nanoscale. J. Biomed. Nanotechnol. 2015, 11, 53-69. [CrossRef] [PubMed]

32. Mitura, S.; Mitura, K.; Niedzielski, P.; Louda, P.; Danilenko, V. Nanocrystalline diamond, its synthesis, properties and applications J. Achiev. Mater. Manuf. Eng. 2006, 16, 7.

33. Catledge, S.A.; Fries, M.D.; Vohra, Y.K.; Lacefield, W.R.; Lemons, J.E.; Woodard, S.; Venugopalan, R. Nanostructured ceramics for biomedical implants. J. Nanosci. Nanotechnol. 2002, 2, 293-312. [CrossRef] [PubMed]

34. Amaral, M.; Gomes, P.S.; Lopes, M.A.; Santos, J.D.; Silva, R.F.; Fernandes, M.H. Nanocrystalline Diamond as a Coating for Joint Implants: Cytotoxicity and Biocompatibility Assessment. J. Nanomater. 2008, 2008, 894352. [CrossRef]

35. Auciello, O.; Birrell, J.; Carlisle, J.A.; Gerbi, J.E.; Xiao, X.; Peng, B.; Espinosa, H.D. Materials science and fabrication processes for a new MEMS technology based on ultrananocrystalline diamond thin films. J. Phys. Condens. Matter 2004, 16, R539-R552. [CrossRef]

36. Auciello, O.; Gurman, P.; Berra, A.; Saravia, M.; Zysler, R. Ultrananocrystalline diamond (UNCD) films for ophthalmological applications. Diam. Based Mater. Biomed. Appl. 2013, 151-170. [CrossRef]

37. Auciello, O.; Sumant, A.V. Status review of the science and technology of ultrananocrystalline diamond (UNCD $\left.{ }^{\mathrm{TM}}\right)$ films and application to multifunctional devices. Diam. Relat. Mater. 2010, 19, 699-718. [CrossRef]

38. Carlisle, J.A.; Gruen, D.M.; Auciello, O.; Xiao, X. Method to Grow Pure Nanocrystalline Diamond Films at Low Temperatures and High Deposition Rates. U.S. Patent 7,556,982, 7 July 2009.

39. Naguib, N.; Elam, J.; Birrell, J.; Wang, J.; Grierson, D.; Kabius, B.; Hiller, J.; Sumant, A.; Carpick, R.; Auciello, O.; et al. Enhanced Nucleation, Smoothness and Conformality of Ultrananocrystalline Diamond (UNCD) Ultrathin Films Via Tungsten Interlayers. Chem. Phys. Lett. 2006, 430, 345-350. [CrossRef]

40. Auciello, O.; Gurman, P.; Guglielmotti, M.; Olmedo, D.; Berra, A.; Saravia, M. Biocompatible ultrananocrystalline diamond coatings for implantable medical devices. MRS Bull. 2014, 39, 621-629. [CrossRef]

41. Carlisle, J.A.; Auciello, O.; Birrell, J. Method to Grow Carbon Thin Films Consisting Entirely of Diamond Grains 3-5 nm in Size and High-Energy Grain Boundaries. U.S. Patent 7,128,889; United States Application No. 10/845,867, 31 October 2006.

42. Zhang, J.; Zimmer, J.W.; Howe, R.T.; Maboudian, R. Characterization of boron-doped micro- and nanocrystalline diamond films deposited by wafer-scale hot filament chemical vapor deposition for MEMS applications. Diam. Relat. Mater. 2008, 17, 23-28. [CrossRef]

43. Tong, W.; Tran, P.A.; Turnley, A.M.; Aramesh, M.; Prawer, S.; Brandt, M.; Fox, K. The influence of sterilization on nitrogen-included ultrananocrystalline diamond for biomedical applications. Mater. Sci. Eng. C Mater. Biol. Appl. 2016, 61, 324-332. [CrossRef] [PubMed]

44. Miksovsky, J.; Voss, A.; Kozarova, R.; Kocourek, T.; Písařík, P.; Ceccone, G.; Kulisch, W.; Jelinek, M.; Apostolova, M.; Reithmaier, J.; et al. Cell adhesion and growth on ultrananocrystalline diamond and diamond-like carbon films after different surface modifications. Appl. Surf. Sci. 2014, 297, 95-102. [CrossRef]

45. Shi, B.; Jin, Q.; Chen, L.; Woods, A.S.; Schultz, A.J.; Auciello, O. Cell Growth on Different Types of Ultrananocrystalline Diamond Thin Films. J. Funct. Biomater. 2012, 3, 588-600. [CrossRef] [PubMed]

46. Fox, K.; Prawer, S. Neural Circuits and In Vivo Monitoring Using Diamond; Elsevier: Amsterdam, The Netherlands, 2014; pp. 291-304.

47. Chen, Y.C.; Lee, D.C.; Hsiao, C.Y.; Chung, Y.F.; Chen, H.C.; Thomas, J.P.; Pong, W.F.; Tai, N.H.; Lin, I.N.; Chiu, I.M. The effect of ultra-nanocrystalline diamond films on the proliferation and differentiation of neural stem cells. Biomaterials 2009, 30, 3428-3435. [CrossRef] [PubMed]

48. Amaral, M.; Dias, A.G.; Gomes, P.S.; Lopes, M.A.; Silva, R.F.; Santos, J.D.; Fernandes, M.H. Nanocrystalline diamond: In vitro biocompatibility assessment by MG63 and human bone marrow cells cultures. J. Biomed. Mater. Res. A 2008, 87, 91-99. [CrossRef] [PubMed]

49. Clem, W.C.; Chowdhury, S.; Catledge, S.A.; Weimer, J.J.; Shaikh, F.M.; Hennessy, K.M.; Konovalov, V.V.; Hill, M.R.; Waterfeld, A.; Bellis, S.L.; et al. Mesenchymal stem cell interaction with ultra-smooth nanostructured diamond for wear-resistant orthopaedic implants. Biomaterials 2008, 29, 3461-3468. [CrossRef]

50. Härtl, A.; Schmich, E.; Garrido, J.A.; Hernando, J.; Catharino, S.C.; Walter, S.; Feulner, P.; Kromka, A.; Steinmüller, D.; Stutzmann, M. Protein-modified nanocrystalline diamond thin films for biosensor applications. Nat. Mater. 2004, 3, 736-742. [CrossRef]

51. Garrett, D.J.; Ganesan, K.; Stacey, A.; Fox, K.; Meffin, H.; Prawer, S. Ultra-nanocrystalline diamond electrodes: Optimization towards neural stimulation applications. J. Neural Eng. 2012, 9, 016002. [CrossRef]

52. Aramesh, M.; Shimoni, O.; Fox, K.; Karle, T.J.; Lohrmann, A.; Ostrikov, K.; Prawer, S.; Cervenka, J. Ultra-high-density 3D DNA arrays within nanoporous biocompatible membranes for single-molecule-level detection and purification of circulating nucleic acids. Nanoscale 2015, 7, 5998-6006. [CrossRef]

53. Ganesan, K.; Garrett, D.J.; Ahnood, A.; Shivdasani, M.N.; Tong, W.; Turnley, A.M.; Fox, K.; Meffin, H.; Prawer, S. An all-diamond, hermetic electrical feedthrough array for a retinal prosthesis. Biomaterials 2014, 35, 908-915. [CrossRef] 
54. Hadjinicolaou, A.E.; Leung, R.T.; Garrett, D.J.; Ganesan, K.; Fox, K.; Nayagam, D.A.; Shivdasani, M.N.; Meffin, H.; Ibbotson, M.R.; Prawer, S.; et al. Electrical stimulation of retinal ganglion cells with diamond and the development of an all diamond retinal prosthesis. Biomaterials 2012, 33, 5812-5820. [CrossRef] [PubMed]

55. Ahnood, A.; Escudie, M.C.; Cicione, R.; Abeyrathne, C.D.; Ganesan, K.; Fox, K.E.; Garrett, D.J.; Stacey, A.; Apollo, N.V.; Lichter, S.G.; et al. Ultrananocrystalline diamond-CMOS device integration route for high acuity retinal prostheses. Biomed. Microdevices 2015, 17, 9952. [CrossRef]

56. Cabrini, R.L.; Guglielmotti, M.B.; Almagro, J.C. Histomorphometry of initial bone healing around zirconium implants in rats Implant Dent. 1993, 2, 264-267. [CrossRef] [PubMed]

57. Jacobs, J.J.; Gilbert, J.L.; Urban, R.M. Corrosion of metal orthopaedic implants. J. Bone Jt. Surg. Am. 1998, 80, 268-282. [CrossRef]

58. Mombelli, A.; Hashim, D.; Cionca, N. What is the impact of titanium particles and biocorrosion on implant survival and complications? A critical review. Clin. Oral Implant. Res. 2018, 29 (Suppl. S18), 37-53. [CrossRef] [PubMed]

59. Olmedo, D.G.; Tasat, D.R.; Duffo, G.; Guglielmotti, M.B.; Cabrini, R.L. The issue of corrosion in dental implants: A review. Acta Odontol. Lat. 2009, 22, 3-9.

60. Duffo, G.; Barreiro, M.; Olmedo, D.; Crosa, M.; Guglielmotti, M.B.; Cabrini, R.L. An experimental model to study implant corrosion. Acta Odontol. Lat. 1999, 12, 3-10.

61. Hallab, N.J.; Jacobs, J.J. Biologic effects of implant debris. Bull. NYU Hosp. Jt. Dis. 2009, 67, 182-188. [PubMed]

62. Allen, M.J.; Myer, B.J.; Millett, P.J.; Rushton, N. The effects of particulate cobalt, chromium and cobalt-chromium alloy on human osteoblast-like cells in vitro. J. Bone Jt. Surg. Br. 1997, 79, 475-482. [CrossRef]

63. Dowd, J.E.; Schwendeman, L.J.; Macaulay, W.; Doyle, J.S.; Shanbhag, A.S.; Wilson, S.; Herndon, J.H.; Rubash, H.E. Aseptic loosening in uncemented total hip arthroplasty in a canine model. Clin. Orthop. Relat. Res. 1995, 319, 106-121. [CrossRef]

64. Lalor, P.A.; Revell, P.A.; Gray, A.B.; Wright, S.; Railton, G.T.; Freeman, M.A. Sensitivity to titanium. A cause of implant failure? J. Bone Jt. Surg. Br. 1991, 73, 25-28. [CrossRef] [PubMed]

65. Matthew, I.; Frame, J.W. Allergic responses to titanium. J. Oral Maxillofac. Surg. 1998, 56, 1466-1467. [CrossRef]

66. Evrard, L.; Waroquier, D.; Parent, D. [Allergies to dental metals. Titanium: A new allergen]. Rev. Med. Brux. 2010, 31, 44-49. [PubMed]

67. Fretwurst, T.; Buzanich, G.; Nahles, S.; Woelber, J.P.; Riesemeier, H.; Nelson, K. Metal elements in tissue with dental periimplantitis: A pilot study. Clin. Oral Implant. Res. 2016, 27, 1178-1186. [CrossRef] [PubMed]

68. Nishimura, K.; Kato, T.; Ito, T.; Oda, T.; Sekine, H.; Yoshinari, M.; Yajima, Y. Influence of titanium ions on cytokine levels of murine splenocytes stimulated with periodontopathic bacterial lipopolysaccharide. Int. J. Oral Maxillofac. Implant. 2014, 29, 472-477. [CrossRef]

69. Daubert, D.; Pozhitkov, A.; McLean, J.; Kotsakis, G. Titanium as a modifier of the peri-implant microbiome structure. Clin. Implant Dent. Relat. Res. 2018, 20, 945-953. [CrossRef]

70. Jacobs, J.J.; Rosenbaum, D.H.; Hay, R.M.; Gitelis, S.; Black, J. Early sarcomatous degeneration near a cementless hip replacement. A case report and review. J. Bone Jt. Surg. Br. 1992, 74, 740-744. [CrossRef]

71. Kaplan, I.; Zeevi, I.; Tal, H.; Rosenfeld, E.; Chaushu, G. Clinicopathologic evaluation of malignancy adjacent to dental implants Oral Surg. Oral Med. Oral Pathol. Oral Radiol. 2017, 123, 103-112. [CrossRef]

72. Baan, R.; Straif, K.; Grosse, Y.; Secretan, B.; El Ghissassi, F.; Cogliano, V. Carcinogenicity of carbon black, titanium dioxide, and talc. Lancet Oncol. 2006, 7, 295-296. [CrossRef]

73. Salgado-Peralvo, A.O.; Arriba-Fuente, L.; Mateos-Moreno, M.V.; Salgado-García, A. Is there an association between dental implants and squamous cell carcinoma? Br. Dent. J. 2016, 221, 645-649. [CrossRef]

74. Case, C.P.; Langkamer, V.G.; Howell, R.T.; Webb, J.; Standen, G.; Palmer, M.; Kemp, A.; Learmonth, I.D. Preliminary observations on possible premalignant changes in bone marrow adjacent to worn total hip arthroplasty implants. Clin. Orthop. Relat. Res. 1996, 329, S269-S279. [CrossRef] [PubMed]

75. Bhola, R.; Bhola, S.M.; Mishra, B.; Ayers, R.; Olson, D.L.; Ohno, T. Cellular response of titanium and its alloys as implants. J. Oral Implant. 2011, 37, 387-399. [CrossRef] [PubMed]

76. Doak, S.; Liu, Y.; Chen, C. Genotoxicity and Cancer; Elsevier: Amsterdam, The Netherlands, 2017; pp. $423-445$.

77. Gottschling, B.C.; Maronpot, R.R.; Hailey, J.R.; Peddada, S.; Moomaw, C.R.; Klaunig, J.E.; Nyska, A. The role of oxidative stress in indium phosphide-induced lung carcinogenesis in rats. Toxicol. Sci. 2001, 64, 28-40. [CrossRef]

78. Kawanishi, S.; Oikawa, S.; Inoue, S.; Nishino, K. Distinct mechanisms of oxidative DNA damage induced by carcinogenic nickel subsulfide and nickel oxides. Environ. Health Perspect. 2002, 110 (Suppl. S5), 789-791. [CrossRef]

79. Mazière, C.; Floret, S.; Santus, R.; Morlière, P.; Marcheux, V.; Mazière, J.C. Impairment of the EGF signaling pathway by the oxidative stress generated with UVA. Free Radic. Biol. Med. 2003, 34, 629-636. [CrossRef]

80. Olmedo, D.G.; Tasat, D.R.; Guglielmotti, M.B.; Cabrini, R.L. Effect of titanium dioxide on the oxidative metabolism of alveolar macrophages: An experimental study in rats. J. Biomed. Mater. Res. A 2005, 73, 142-149. [CrossRef]

81. Oberdörster, G.; Maynard, A.; Donaldson, K.; Castranova, V.; Fitzpatrick, J.; Ausman, K.; Carter, J.; Karn, B.; Kreyling, W.; Lai, D.; et al. Principles for characterizing the potential human health effects from exposure to nanomaterials: Elements of a screening strategy. Part. Fibre Toxicol. 2005, 2, 8. [CrossRef]

82. Donaldson, K.; Brown, D.; Clouter, A.; Duffin, R.; MacNee, W.; Renwick, L.; Tran, L.; Stone, V. The pulmonary toxicology of ultrafine particles. J. Aerosol. Med. 2002, 15, 213-220. [CrossRef] 
83. Tasat, D.R.; Mancuso, R.; O'Connor, S.; Molinari, B. Age-dependent change in reactive oxygen species and nitric oxide generation by rat alveolar macrophages. Aging Cell 2003, 2, 159-164. [CrossRef]

84. Bruno, M.E.; Tasat, D.R.; Ramos, E.; Paparella, M.L.; Evelson, P.; Rebagliati, R.J.; Cabrini, R.L.; Guglielmotti, M.B.; Olmedo, D.G. Impact through time of different sized titanium dioxide particles on biochemical and histopathological parameters. J. Biomed. Mater. Res. A 2014, 102, 1439-1448. [CrossRef]

85. Sumant, A.; Krauss, A.; Gruen, D.; Auciello, O.; Erdemir, A.; Williams, M.; Artiles, A.F.; Adams, W.; Corp, F. Ultrananocrystalline Diamond Film as a Wear-Resistant and Protective Coating for Mechanical Seal Applications. Tribol. Trans. 2005, 48, 24-31. [CrossRef]

86. Tasat, D.R.; Bruno, M.E.; Domingo, M.; Gurman, P.; Auciello, O.; Paparella, M.L.; Evelson, P.; Guglielmotti, M.B.; Olmedo, D.G. Biokinetics and tissue response to ultrananocrystalline diamond nanoparticles employed as coating for biomedical devices. J. Biomed. Mater. Res. B Appl. Biomater. 2017, 105, 2408-2415. [CrossRef] [PubMed]

87. Ivanova, L.; Popov, C.; Kolev, I.; Shivachev, B.; Karadjov, J.; Tarassov, M.; Kulisch, W.; Reithmaier, J.; Apostolova, M. Nanocrystalline diamond containing hydrogels and coatings for acceleration of osteogenesis. Diam. Relat. Mater. 2011, 20, 165-169. [CrossRef]

88. Kang, K.; Auciello, O.; Olmedo, D.G.; Tasat, D.R.; López-Chávez, G. Science and technology of ultrananocrystalline diamond (UNCD TM) coatings for new generation of implantable prostheses: Dental implants, artificial hips and knees. In Ultrananocrystalline Diamond Coatings for Next-Generation High-Tech and Medical Devices; Auciello, O., Ed.; Cambridge University Press: Cambridge, UK, 2022. 